\title{
Financial performance, employee well-being, and client well-being in for-profit and not-for-profit nursing homes: A systematic review
}

\author{
Aline Bos \\ Paul Boselie \\ Margo Trappenburg
}

Background: Expanding the opportunities for for-profit nursing home care is a central theme in the debate on the sustainable organization of the growing nursing home sector in Western countries.

Purposes: We conducted a systematic review of the literature over the last 10 years in order to determine the broad impact of nursing home ownership in the United States. Our review has two main goals: (a) to find out which topics have been studied with regard to financial performance, employee well-being, and client well-being in relation to nursing home ownership and (b) to assess the conclusions related to these topics. The review results in two propositions on the interactions between financial performance, employee well-being, and client well-being as they relate to nursing home ownership. Methodology/Approach: Five search strategies plus inclusion and quality assessment criteria were applied to identify and select eligible studies. As a result, 50 studies were included in the review. Relevant findings were categorized as related to financial performance (profit margins, efficiency), employee well-being (staffing levels, turnover rates, job satisfaction, job benefits), or client well-being (care quality, hospitalization rates, lawsuits/complaints) and then analyzed based on common characteristics.

Findings: For-profit nursing homes tend to have better financial performance, but worse results with regard to employee well-being and client well-being, compared to not-for-profit sector homes. We argue that the better financial performance of for-profit nursing homes seems to be associated with worse employee and client well-being.

Practical Implications: For policy makers considering the expansion of the for-profit sector in the nursing home industry, our findings suggest the need for a broad perspective, simultaneously weighing the potential benefits and drawbacks for the organization, its employees, and its clients.

Key words: for-profit, nursing homes, performance, systematic review, well-being

Aline Bos, MSc, is PhD Student, Utrecht University School of Governance, the Netherlands. E-mail: A.Bos@uu.nl.

Paul Boselie, PhD, is Professor of Strategic Human Resource Management, Utrecht University School of Governance, the Netherlands.

Margo Trappenburg, PhD, is Professor of Social work, University of Humanistic Studies, Utrecht, the Netherlands, and Associate Professor, Utrecht University School of Governance, the Netherlands.

This research received no specific grant from any funding agency in the public, commercial, or NFP sectors. The Appendices A and B, as referred to in the article, are available online as supplemental digital content.

The authors have disclosed that they have no significant relationship with, or financial interest in, any commercial companies pertaining to this article. Supplemental digital content is available for this article. Direct URL citations appear in the printed text and are provided in the HTML and PDF versions of this article on the journal's Web site (www.hcmrjournal.com).

DOI: 10.1097/HMR.0000000000000121 
$\mathrm{A}$ nursing home is viewed as a place of residence for people who require round-the-clock nursing care and have significant difficulty coping with the required activities for daily living. In the United States, over half of all nursing home residents are aged 85 or older. Nursing home residents experience a wide array of physical or mental disorders, and most of them can be considered as long-term care patients: They will never recover to the point where they can take care of themselves (Sengupta, Harris-Kojetin, \& Caffrey, 2015).

The demand for nursing home care is likely to grow. The number of people in the 80 years and above category is growing faster than any other segment of the population. The European Union forecasts that public expenditure on long-term care will almost double by 2060 in its member states (European Commission, 2012, p. 197, 224). Likewise, the number of people using long-term care services in the United States "is projected to increase from 15 million in 2000 to 27 million in 2050" (U.S. Department of Health and Human Services, 2013, p. 3). This growth poses challenges in terms of both costs and care quality with regard to the sustainable organization of the nursing home sector. A central question is whether nursing home care should be delivered by for-profit (FP) or not-for-profit (NFP) providers.

In Western countries, long-term care for frail elderly people is delivered through a mix of FP and NFP facilities. In the United States, $68 \%$ of all nursing homes are FP (U.S. Department of Health and Human Services, 2013). In the United Kingdom, $42 \%$ of the major care home providers (i.e., those with three or more homes) for older and physically disabled people are FP, and $55 \%$ of all care home beds are in FP facilities (Forder \& Allan, 2011, p. 13). Eight of the 10 largest U.K. care home providers are FP companies (Lakhani \& Whittell, 2012). In Canada, the mix of providers varies by province, with for example $52 \%$ FP nursing homes in Ontario, 30\% in British Columbia, and 15\% in Manitoba (McGregor et al., 2006). European countries also vary in the extent to which they allow or encourage FP nursing homes. In the Netherlands, FP nursing homes are not allowed, although an exception is made for private, small-scale facilities. In Finland and Sweden, where nursing home care was traditionally run by the public sector, an increasing number of private FP providers have established themselves in the market (Heponiemi, Elovainio, Kouvonen, Kuusio, et al., 2011; Heponiemi, Elovainio, Kouvonen, Noro, et al., 2011; Kirsebom, Hedström, Wadensten, \& Pöder, 2014, p. 116).

Opinions differ strongly as to the desirability of extending the trend of growing FP nursing home care (e.g. Dyson, 2014; Sennero \& Pollard, 2014; U.S. Government Accountability Office, 2010). The key difference between FP and NFP nursing homes is in the identity of those who possess ultimate control over them, owners versus boards of trustees: "the wealth of owners of FP nursing homes is tied to the financial success of the nursing home in which they have ownership stakes, whereas the individuals who control NFP nursing homes have no legal ownership stakes" (Ben-Ner \& Ren, 2008, p. 2). If income exceeds operational costs, NFP nursing homes typically put that "profit" back into the facility. An FP provider may choose its own objectives, resources, and management perspectives, and this can affect the nursing home organization as a whole, its employees, and its clients. It is claimed that FP providers can contribute to leaner nursing home organizations and improved management control systems that will keep costs under control (e.g., Weech-Maldonado, Laberge, Pradhan, Johnson, \& Hyer, 2012). FP providers may also feel pressure to compete on price and quality, and this may result in higher-quality care that is also more efficiently organized (Konetzka, 2009). However, FP nursing homes may favor financial returns for their owners over high-quality care (e.g., Kitchener, O'Meara, Brody, Lee, \& Harrington, 2008). If, as is likely, their management objective is to provide returns to investors, FP owners could prioritize profits over employee and client well-being (e.g., Harrington, Zimmerman, Karon, Robinson, \& Beutel, 2000).

Given these uncertainties, we present a systematic review of the literature published between 2004 and 2014 on the role of nursing home ownership in the United States and compare evidence on FP and NFP nursing homes in the private sector. We have focused on the United States because most studies on this topic relate to American nursing homes. We build on insights from the Human Resource Management (HRM) literature on multistakeholder perspectives by distinguishing relevant differences for the organization as a whole, its employees, and its clients (Beer, Spector, Lawrence, Mills, \& Walton, 1984). The main aim of this review is to qualitatively assess and summarize current evidence related to the effect of nursing home profit status by answering two research questions:

RQ1: What topics have been studied with regard to financial performance, employee well-being, and client well-being in relation to nursing home ownership?

RQ2: What are the outcomes of these topics for financial performance, employee well-being, and client well-being, and how are these outcomes related to each other?

On the basis of the findings, we offer two propositions on the interaction between financial performance, employee well-being, and client well-being as related to nursing home ownership.

Previous reviews of FP nursing home ownership have focused on the relationship between ownership and quality of care indicators (Comondore et al., 2009; Hillmer, Wodchis, Gill, Anderson, \& Rochon, 2005). Furthermore, more than $80 \%$ of the articles used in these earlier reviews were published prior to 2004, meaning that these reviews are mainly based on publications that are now more than a decade old.

Our systematic review of the literature on FP and NFP nursing homes makes two contributions. First, it updates 
the earlier reviews by assessing articles published between 2004 and 2014, with 72\% of the articles reviewed here not having been included in previous reviews. Second, whereas previous reviews have concluded that FP nursing homes appear to provide lower-quality care (Comondore et al., 2009, Hillmer et al., 2005), our systematic review synthesizes the accumulated evidence on a much broader spectrum of criteria. We regard care quality as just one of the possible indicators of client well-being and also consider hospitalization rates and the incidence of lawsuits and complaints. Furthermore, we also include differences between FP and NFP nursing homes with regard to financial performance and employee well-being. Our presumption is that there will be some kind of relationship between financial performance, employee well-being, and client wellbeing, although we are unsure as to the nature of that relationship. In addition, we include studies where the ownership status is the independent variable and others where ownership is a covariate.

\section{Theoretical Framework}

We view nursing home performance as a multidimensional construct, incorporating variables that are relevant to various stakeholders (i.e., owners, employees, and clients). We build on HRM research, in which Beer et al. (1984) distinguish multiple stakeholders and define multidimensional performances for HRM policy and practice outcomes, including organizational effectiveness (e.g., financial outcomes) and individual well-being (e.g., satisfaction). Various scholars have stressed the need to balance a range of outcomes, and by treating nursing homes as social systems, we place the outcomes for the different stakeholders at the center of our study. Our premise is that performance is created in the way that owners, employees, and clients are jointly affected by a nursing home's type of ownership (Freeman, Harrison, Wicks, Parmar, \& De Colle, 2010). Taking a broad perspective, this review explores whether positive outcomes for one stakeholder come at the expense of other stakeholders, or whether all can gain. We therefore introduce two competing perspectives derived from the literature on HRM and performance (e.g., Van De Voorde, Paauwe, \& Van Veldhoven, 2012): the "mutual gains perspective" and the "conflicting outcomes perspective."

\section{Mutual Gains Perspective}

The "mutual gains perspective" holds that positive/negative outcomes for one stakeholder are accompanied with similar outcomes for other stakeholders. For example, if nursing homes provide inferior care quality, this is accompanied by a poor financial outcome. This "mutual gains perspective" states that the outcomes on different dimensions reinforce each other in the same direction. Recognition of this perspective is seen in the expression "doing well by doing good": Paying attention to all stakeholders will benefit all stakeholders (Falck \& Heblich, 2007; Laszlo, 2008). In this regard, FP nursing homes might function as not-just-for-profit homes and purposefully treat the multiple stakeholders in a balanced way, because this provides a win-win situation. Several studies in the area of HRM indeed highlight the possibility to create parallel positive outcomes for both employees and employers (e.g., Macky \& Boxall, 2007).

\section{Conflicting Outcomes Perspective}

Arguing from the alternative "conflicting outcomes perspective," a skeptical view can be perceived of the concept of performance as a multidimensional construct. The conflicting outcomes perspective views the maximization of value for one stakeholder as not necessarily benefitting other stakeholders. Hence, the overall impact of a nursing home profit status may be a trade-off in terms of positive and negative outcomes for the different stakeholders. For example, if an FP nursing home adopts a profit maximization perspective - with a focus on economic efficiency, minimizing costs and maximizing profit for shareholdersthis may well come at the expense of employee well-being (e.g., fewer staff and therefore higher work pressure) and client well-being (e.g., higher incidence of pressure ulcers). In comparison, NFP facilities may emphasize public service values by prioritizing medical and personnel aspects of care and reinvesting their revenues back in the facilities (e.g., Haley-Lock \& Kruzick, 2008; Harrington et al., 2000; Heponiemi, Elovainio, Kouvonen, Kuusio, et al., 2011; Heponiemi, Elovainio, Kouvonen, Noro, et al., 2011). The broader HRM literature observes the possibility of conflicting outcomes related to employee well-being and financial performance. For instance, a high level of people orientation in leadership has been related to low financial performance (Van Veldhoven, 2005), while aiming for high financial performance may come at the cost of intensified work and job strain for employees (Ramsay, Scholarios, \& Harley, 2000).

To summarize, the "conflicting outcomes perspective" sees potential trade-offs in different dimensions of performance, whereas the "mutual gains perspective" assumes that the outcomes for the different stakeholders will reinforce each other in the same positive or negative direction. By using a multidimensional performance construct, we explore which of these perspectives is most appropriate for describing the impact of FP ownership in comparison to NFP ownership of nursing homes.

\section{Method}

Our systematic review of the literature is based on the replicable and transparent steps specified in the PRISMA method (Liberati et al., 2009). The PRISMA checklist 
in Appendix B (see Appendix B, Supplemental Digital Content 2, http://links.lww.com/HCMR/A18) records how we followed the required steps.

\section{Data Sources and Searches}

The PiCarta, Scopus, PubMed, Google Scholar, and Web of Science databases were searched for relevant studies. The searches were conducted in January 2015. The references of retrieved articles were manually searched for further material. The terms searched for in titles and abstracts were "health care/health services AND ownership," "for profit nursing home," "investor-owned AND health care," "profit AND health care," and "ownership conversion AND health care."

\section{Inclusion Criteria}

We used six inclusion criteria in selecting or rejecting studies identified in the database searches. First, they had to be in English. Second, we only included studies that were published between 2004 and 2014. Third, we only reviewed studies that were published in peer-reviewed journals. Fourth, we only selected studies that included United Statesbased research. Fifth, studies had to be empirical, and we excluded commentaries, reviews, and theoretical analyses. Sixth, studies had to have investigated the differences between private FP and private NFP nursing homes in terms of variables that were relevant to financial performance, employee well-being, or client well-being. Only studies that satisfied all six criteria were included in the review.

\section{Variables}

The central variable is the profit status of nursing homes. We study whether a nursing home's profit status influences the variables that emerge from our review. These variables are categorized into the dimensions of "financial performance," "employee well-being," and "client well-being."

Nursing home profit status. Generally, three types of ownership can be distinguished within the nursing home industry: public, private FP, and private NFP. Our review focuses on the differences between private FP and private NFP nursing homes. Several of the studies we reviewed also included public facilities in their sample. As our focus is on the difference between private FP and private NFP nursing homes, we excluded the results for public homes from our analysis. We did this for three reasons. First, the nature of many public nursing homes is distinct from that of private ones. Public facilities are often linked to particular populations (e.g., military veterans) or serve as a safety net (e.g., many city or county facilities; Grabowski, Feng, Hirth, Rahman, \& Mor, 2013, p. 15). Moreover, there are relatively few public nursing home facilities in the United
States (6.8\%: U.S. Department of Health and Human Services, 2013). Second, the available evidence pushes us in this direction, because most of the studies ( $57 \%$ of the studies included in our review) treat ownership as a dummy variable (FP vs. NFP). Third, the studies that do include public homes as a separate category mainly show that the results of FP nursing homes can be contrasted with those of NFP and public nursing homes (Amirkhanyan, Kim, \& Lambright, 2008; Dobalian, 2004; Grabowski \& Angelelli, 2004; Haley-Lock \& Kruzich, 2008; Mueller et al., 2006; Park \& Stearns, 2009; Seblega et al., 2010; Zhang, Unruh, \& Wan, 2008; Zinn, Spector, Hsieh, \& Mukamel, 2005). Another subset of the studies that distinguish public homes do not report results for this specific category (Akinci \& Krolikowski, 2005; Konetzka, Norton, Sloane, Kilpatrick, \& Stearns, 2006). The number of studies that report differences between NFP and government facilities is relatively small (Bardenheier, Shefer, Tiggle, Marsteller, \& Remsburg, 2005; Grabowski, Angelelli, \& Mor, 2004; Konetzka, Spector, \& Shaffer, 2004; Konetzka, Yi, Norton, \& Kilpatrick, 2004; Zhang \& Grabowski, 2004). For these three reasons, we treat the profit status of a nursing home as a dummy variable.

Financial performance. Financial performance covers variables that affect the performance of the organization as a whole; in our study, the variables used address profit margins and efficiency.

Employee well-being. "Ownership is an important structural factor to consider as an influence on human services job quality because of its presumed relationship to organizational goals and behavior" (Haley-Lock \& Kruzich, 2008, p. 448). We treat employee well-being as a broad concept that includes both subjective employee experiences (such as satisfaction) as well as objective measures of working conditions. In this area, the following variables emerged from our literature review: staffing levels, turnover rates, job benefits, and job satisfaction.

Staffing levels were mainly presented as hours per resident day, as an indicator of the time professionals have for carrying out their tasks in a fulfilling way. Several studies regard staffing levels as a structural measure of care quality (e.g., Hillmer et al., 2005). However, we treat staffing level as an employee well-being variable because (a) research on the relationship between staffing levels and direct quality of care suggests analytical differences between them, for example, in studying the impact of staffing on resident outcomes (e.g., Schnelle et al., 2004) and (b) the quality of nurses' working life is related to staffing levels with staffing adequacy having been directly related to work intensification and emotional exhaustion (Aiken, Clarke, Sloane, Sochalski, \& Silber, 2002; Laschinger \& Leiter, 2006). Turnover rates are an indicator of HRM practices, with long-term investments leading to lower turnover (Batt \& Colvin, 2011). Job benefits include salaries and staff training. In general, these variables have been related to 
job satisfaction (e.g., Harter, Schmidt, \& Hayes, 2002), but job satisfaction is also included as a separate variable to reflect an employee's perceived well-being in terms of the job and working conditions.

Client well-being. We relate client well-being to direct care quality outcomes, hospitalization rates, and the rate of lawsuits and complaints. Care quality can be defined by clinical measures, such as the prevalence of catheter use, pressure ulcers, and use of antipsychotic medication. A second dimension of care quality is the number of serious deficiencies identified in facilities that fail to meet the federal standards for Medicare and Medicaid participation. Deficiencies provide an overall measure of quality.

The second variable linked to client well-being is the number of hospitalizations linked to a nursing home. This is justified on the basis that most of the hospitalizations are potentially avoidable (Givens, Selby, Goldfeld, \& Mitchell, 2012). We have categorized hospitalizations as a client well-being variable, because hospitalization is likely to be physically and mentally stressful for frail elderly people living in nursing homes and may result in a further decline in health and have limited clinical benefit.

Finally, we include the number of lawsuits and complaints as a client well-being variable and include articles that investigate their prevalence in FP and NFP nursing homes as an indicator of client satisfaction. Figure 1 summarizes the indicators that emerge from our literature search for each dimension distinguished.

We judge the outcomes on each dimension from the perspective of the relevant stakeholder (i.e., the organization as a whole, the employee, or the client). For example, higher profit margins are regarded from the organizational point of view as positive results, and higher staffing levels are evaluated from an employee perspective as positive.

\section{Figure 1}

\section{Conceptual framework}

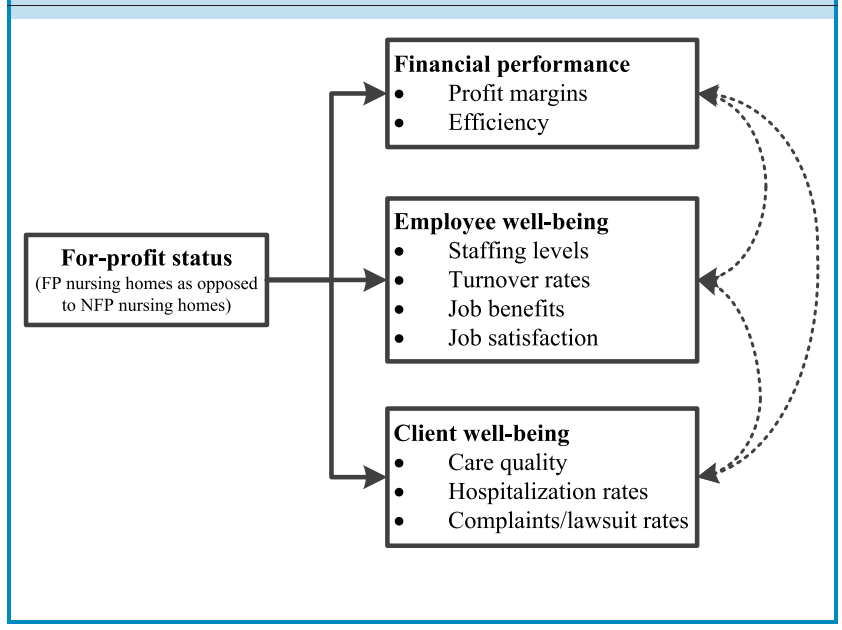

\section{Quality Assessment}

In the final part of the review, we analyzed each study for its methodological quality using a quality assessment tool to remove low-quality studies. This tool uses eight criteria to assess three study aspects: design, sampling, and statistical analysis. The tool was adapted from an instrument developed by Cummings et al. (2010) that has been used in earlier systematic reviews (e.g., Bronkhorst, Tummers, Steijn, \& Vijverberg, 2014). Appendix A (see Appendix A, Supplemental Digital Content 1, http://links.lww.com/HCMR/ A17) summarizes the quality assessment findings and provides the quality scores for the individual articles. We stress the findings of high-quality studies in our findings.

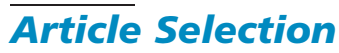

The decision to include a study was determined in a threestep procedure. First, the bibliographic data and abstracts of retrieved studies were evaluated for concordance with the formal inclusion rules (the first four inclusion criteria). Studies that failed any criteria were discarded at this stage. The full texts of the 83 remaining studies were retrieved for critical appraisal. We then consulted senior scholars in the field to add to our list of relevant studies for the subsequent in-depth analysis. In the second step of the inclusion procedure, the full texts were checked against all six criteria and excluded if they did not satisfy all the criteria. In reviewing the full texts, studies were classified according to their focus into the "financial performance," "employee well-being," and "client well-being" categories. We extracted the publication year and journal title, the country of origin, the methods used, and relevant findings and placed this information in a database.

\section{Results}

\section{Search Results}

The database searches yielded 2,028 potential articles. Another 58 studies were identified through the manual review of references, resulting in a total of 2,086 candidate articles (Figure 2). Using the selection criteria, 83 of these studies were identified for full-text retrieval and in-depth study. Next, 11 additional articles were identified by six senior scholars in the field (see Acknowledgments), leading to 94 full texts for in-depth review.

Of these, 27 were then rejected because they did not address the topic of our study (e.g., focusing on variables such as nursing home market structure that transcended the organizational level) and six because they did not present empirical data (review articles, etc.). We then applied the quality assessment tool (see Appendix A, Supplemental 


\section{Figure 2}

\section{Flow diagram for search and selection processes}

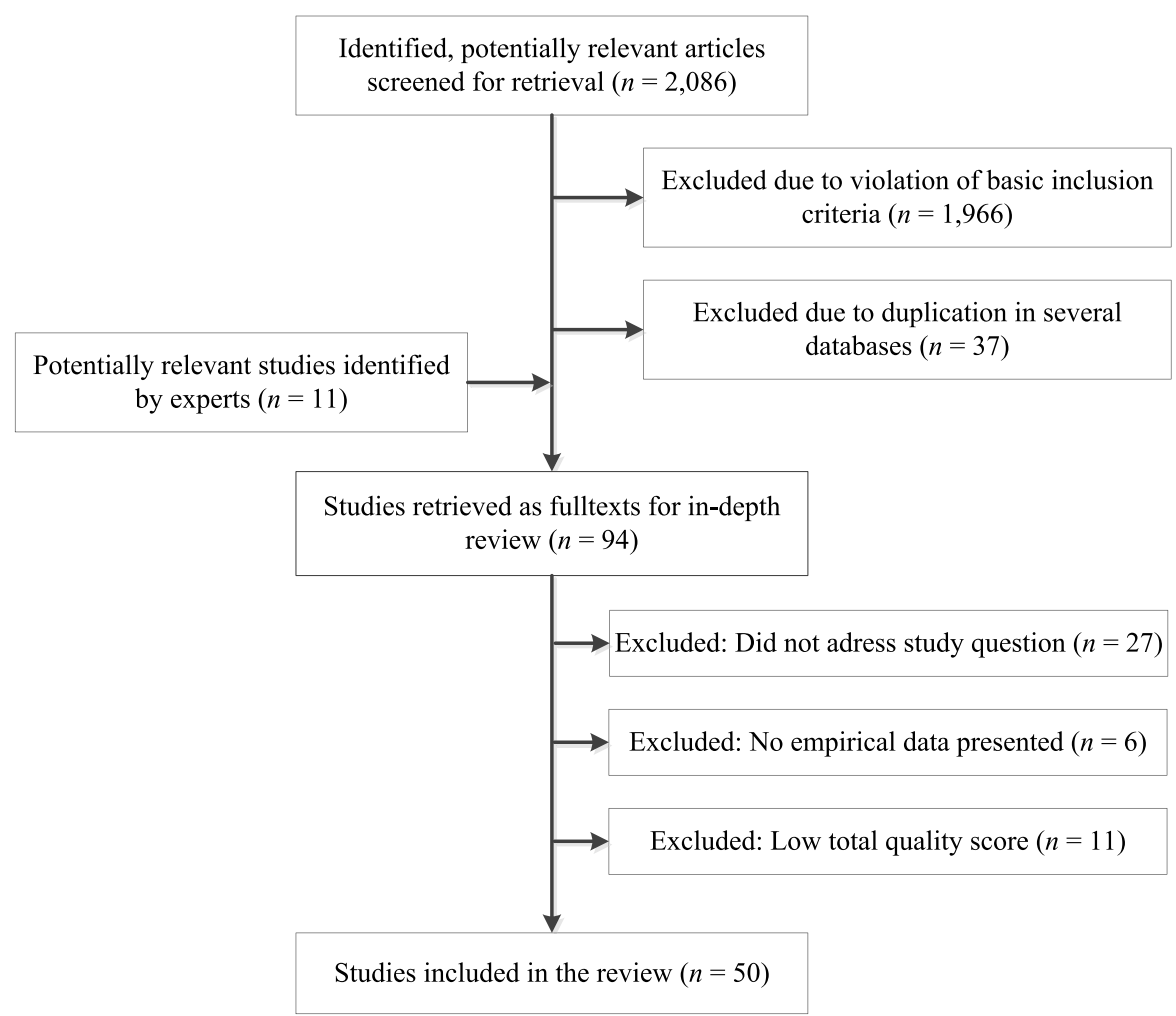

Digital Content 1, http://links.lww.com/HCMR/A17) to the remaining 61 studies, and another 11 were excluded because they were rated as low quality. At the end of this process, 50 publications had therefore satisfied all the criteria and were included in the review.

Having established our sample, we first considered some characteristics of the papers found. First, we noted a downward trend in the number of articles over time. The publications mostly reported quantitative studies, with only three studies combining quantitative and qualitative methods (see Table 1). Twenty-nine of the included studies $(58 \%)$ drew some of their data from the same data source, namely the Online Survey, Certification, and Reporting data network maintained by the Centers for Medicare and Medicaid Services (2013) in cooperation with statewide long-term care surveying agencies. Only one study focused on financial performance and employee well-being variables simultaneously (Kash, Castle, \& Phillips, 2007). Four others combined employee well-being and client well-being variables (Akinci \& Krolikowski, 2005; Decker, 2006; Grabowski \& Stevenson, 2008; Konetzka, Yi, et al., 2004). Thus, only 5 of the 50 studies (10\%) have included variables related to more than one of the dimensions distinguished in this review.

\begin{tabular}{|c|c|}
\hline \multicolumn{2}{|c|}{$\begin{array}{l}\text { Details of the studies included in the } \\
\text { review }(N=50)\end{array}$} \\
\hline Study characteristic & Included studies, $n(\%)$ \\
\hline \multicolumn{2}{|l|}{ Type of empirical study } \\
\hline Quantitative & $47(94 \%)$ \\
\hline Quantitative and qualitative & $3(6 \%)$ \\
\hline \multicolumn{2}{|l|}{ Design } \\
\hline Cross-sectional & $49(98 \%)$ \\
\hline Longitudinal & $1(2 \%)$ \\
\hline \multicolumn{2}{|l|}{ Publication year } \\
\hline 2004-2006 & $28(56 \%)$ \\
\hline 2007-2009 & $16(32 \%)$ \\
\hline 2010-2012 & $3(6 \%)$ \\
\hline 2013-2014 & $3(6 \%)$ \\
\hline \multicolumn{2}{|l|}{ Focus of article ${ }^{a}$} \\
\hline Financial performance & $6(12 \%)$ \\
\hline Employee well-being & $18(36 \%)$ \\
\hline Client well-being & $30(60 \%)$ \\
\hline
\end{tabular}

aSome studies focus on more than one variable, thereby covering more than one dimension. The total number of studies focusing on each of the three performance aspects is therefore higher than the total number of individual studies in the review. 
In half of the studies reviewed, ownership was treated as an independent variable and, as such, the main focus. The other studies used ownership as a control variable (or covariate), and these are indicated by the superscript ${ }^{c}$ in the tables (and listed below those adopting the independent variable approach). The proportion of FP nursing homes in the individual studies ranged from $44 \%$ to $86 \%$, and the proportion of NFP homes from $14 \%$ to $51 \%$. The average split between FP and NFP homes across all the samples was $69 \%-29 \%$, which is roughly in line with the $68 \%-25 \%$ distribution of ownership types in the U.S. nursing home industry (U.S. Department of Health and Human Services, 2013).

\section{Profit Status and Financial Performance}

Six of the studies (12\%) included in the review focus on the differences in financial performance between FP and NFP nursing homes (see Table 2).

Profit margins. Two of these studies addressed differences in profit margin between FP and NFP nursing homes and found that FP nursing homes have significantly higher profit margins (Kash et al., 2007; Weech-Maldonado et al., 2012). These are seen as robust outcomes because both studies control for relevant organizational and market level variables, such as chain membership, case mix, per capita income, and market competition, in determining the relationship between ownership and profit margins.

Efficiency. Two of the other studies show that FP nursing homes have higher efficiency levels than NFP ones (Lee,
Bott, Gajewski, \& Taunton, 2009; Zhang et al., 2008). The first of these controlled for quality variations, whereas ownership is only a covariate in the second.

Two other studies had findings that we link to financial performance. First, the study by Davis, Marino, Aaron, and Tolbert (2009) shows no differences between NFPs and FPs in the extent to which they can be associated with innovativeness, risk-taking, and proactiveness (i.e., entrepreneurial orientation). Second, the study by Givens et al. (2013) concludes that FP nursing homes are more likely to transfer their residents to skilled nursing units and suggests that this is due to financial considerations with the Medicare payments for skilled nursing services much higher than the Medicaid daily rate for long-term nursing home care.

Overall, evidence on financial performance is relatively scarce. The few studies identified show that nursing homes with an FP status can be associated with higher profit margins and higher efficiency levels. Furthermore, although Davis et al. (2009) failed to find differences between FP and NFP nursing homes with regard to their entrepreneurial orientation, Givens et al. (2013) suggest that FP homes do weigh financial considerations more seriously in their referral decisions than NFP homes.

\section{Profit Status and Employee Well-being}

Eighteen of the 50 studies reviewed (36\%) include employee well-being variables (see Table 3 ). The most prevalent variable used was staffing levels, although turnover was also prominent. We also found some studies addressing job satisfaction and job benefits.

\begin{tabular}{|c|c|c|}
\hline \multicolumn{3}{|c|}{ Table 2} \\
\hline Reference & Sample & $\begin{array}{l}\text { Relevant findings: FP vs. NFP } \\
\text { nursing homes }\end{array}$ \\
\hline \multicolumn{3}{|l|}{ Profit margin } \\
\hline $\begin{array}{l}\text { Kash et al., 2007, Health Care } \\
\text { Management Review }\end{array}$ & 1,014 Texas facilities & FPs: higher operating profit margins \\
\hline $\begin{array}{l}\text { Weech-Maldonado et al., 2012, } \\
\text { Health Care Management Review } \\
\text { Efficiency }\end{array}$ & 11,236 U.S. facilities & FPs: higher operating and total margins \\
\hline Lee et al., 2009, Health Services Research & 107 Kansas and Missouri facilities & FPs: more efficient \\
\hline $\begin{array}{l}\text { Zhang et al., 2008, Health } \\
\text { Services Research }{ }^{c}\end{array}$ & 8,361 U.S. facilities & FPs: more efficient \\
\hline \multicolumn{3}{|l|}{ Other } \\
\hline $\begin{array}{l}\text { Davis et al., 2009, Nonprofit and } \\
\text { Voluntary Sector Quarterly }\end{array}$ & $\begin{array}{l}134 \text { Florida nursing home } \\
\text { administrators }\end{array}$ & $\begin{array}{l}\text { No differences in entrepreneurial } \\
\text { orientation of FPs and NFPs }\end{array}$ \\
\hline $\begin{array}{l}\text { Givens et al., 2013, Journal of the } \\
\text { American Geriatrics Society }\end{array}$ & $\begin{array}{l}\text { 4,177 U.S. nursing home residents } \\
\text { with advanced dementia }\end{array}$ & $\begin{array}{l}\text { FPs: more likely to refer to skilled } \\
\text { nursing home (possibly because } \\
\text { of financial considerations) }\end{array}$ \\
\hline
\end{tabular}




\begin{tabular}{|c|c|c|}
\hline \multicolumn{3}{|c|}{ Table 3} \\
\hline \multicolumn{3}{|c|}{ Details of studies that assessed employee well-being } \\
\hline Reference & Sample & $\begin{array}{l}\text { Relevant findings: FP vs. NFP } \\
\text { nursing homes }\end{array}$ \\
\hline \multicolumn{3}{|l|}{$\begin{array}{l}\text { Staffing (occupational categories: } \\
\text { RN, LVN, CNA) }\end{array}$} \\
\hline $\begin{array}{l}\text { Grabowski \& Stevenson, 2008, } \\
\text { Health Services Research }\end{array}$ & $\begin{array}{l}\text { 194,556 U.S. OSCAR surveys; 383,937 } \\
\text { facility-quarter records }\end{array}$ & $\begin{array}{l}\text { RN staffing levels decrease after } \\
\text { conversion from NFP to FP }\end{array}$ \\
\hline Kash et al., 2006, The Gerontologist & 1,014 Texas facilities & $\begin{array}{l}\text { FPs: lower staffing levels in each } \\
\text { occupational category }\end{array}$ \\
\hline Rantz et al., 2004, The Gerontologist & 92 Missouri facilities & $\begin{array}{l}\text { No significant differences in } \\
\text { overall staffing levels }\end{array}$ \\
\hline $\begin{array}{l}\text { Seblega et al., 2010, Medical Care } \\
\text { Research and Review }\end{array}$ & 11,611 U.S. facilities & $\begin{array}{l}\text { FPs: lowest mean values for all } \\
\text { types of nursing staff and lower } \\
\text { skills mix }\end{array}$ \\
\hline $\begin{array}{l}\text { Akinci \& Krolikowski, 2005, Applied } \\
\text { Nursing Research }{ }^{\text {c }}\end{array}$ & 90 Pennsylvanian facilities & $\begin{array}{l}\text { FPs: lower staffing levels for each } \\
\text { occupational category }\end{array}$ \\
\hline $\begin{array}{l}\text { Decker, 2008, Health Economics, } \\
\text { Policy, and Law }{ }^{c}\end{array}$ & $\begin{array}{l}\text { 10,606 U.S. facilities; } \\
21,212 \text { observations }\end{array}$ & FPs: lower RN staffing levels \\
\hline $\begin{array}{l}\text { Feng, Grabowski, Intrator, Zinn, \& } \\
\text { Mor, 2008, Medical Care }\end{array}$ & $\begin{array}{l}\text { 9,996 U.S. facilities; } 77,622 \\
\text { observations }\end{array}$ & $\begin{array}{l}\text { FPs: lower staffing levels for each } \\
\text { occupational category }\end{array}$ \\
\hline Intrator et al., 2005, The Gerontologist ${ }^{c}$ & 17,635 U.S. facilities; 137,190 & $\begin{array}{l}\text { No differences with regard to } \\
\text { the staffing of nurse } \\
\text { practitioners and physician } \\
\text { assistants (dummy variable) }\end{array}$ \\
\hline $\begin{array}{l}\text { Konetzka, Yi, et al., 2004, } \\
\text { Health Services Research c }\end{array}$ & $\begin{array}{l}\text { 60,283 surveys from 18,134 } \\
\text { U.S. facilities }\end{array}$ & $\begin{array}{l}\text { FPs: lower staffing levels (significant } \\
\text { for RNs, RNs + LVNs, CNAs, } p<.001 \text { ) }\end{array}$ \\
\hline Mueller et al., 2006, The Gerontologist ${ }^{c}$ & 14,147 U.S. facilities & $\begin{array}{l}\text { FPs: significantly lower total, LVN, } \\
\text { and CNA staffing levels }\end{array}$ \\
\hline $\begin{array}{l}\text { Park \& Stearns, 2009, } \\
\text { Health Services Research }{ }^{c} \\
\text { Turnover }\end{array}$ & $\begin{array}{l}\text { 15,217 U.S. facilities; } 55,248 \\
\text { facility-year observations }\end{array}$ & $\begin{array}{l}\text { FPs: more likely to be low-staff } \\
\text { facilities }(p<.01)\end{array}$ \\
\hline $\begin{array}{l}\text { Castle \& Engberg, 2006, } \\
\text { The Gerontologist }\end{array}$ & $\begin{array}{l}854 \text { facilities in Missouri, Texas, } \\
\text { Connecticut, New York } \\
\text { Pennsylvania, New Jersey }\end{array}$ & $\begin{array}{l}\text { FPs: higher turnover for all } \\
\text { occupational categories }\end{array}$ \\
\hline Kash et al. 2006, The Gerontologist & 1,014 Texas facilities & $\begin{array}{l}\text { FPs: higher turnover for all } \\
\text { occupational categories }\end{array}$ \\
\hline Castle, 2005, The Gerontologist ${ }^{c}$ & $\begin{array}{l}419 \text { facilities in Kansas, Maine, } \\
\text { Mississippi, South Dakota, Texas }\end{array}$ & $\begin{array}{l}\text { FPs: higher turnover for all } \\
\text { occupational categories }\end{array}$ \\
\hline Castle et al., 2007, The Gerontologist ${ }^{c}$ & $\begin{array}{c}72 \text { facilities in Colorado, Florida, } \\
\text { Michigan, New York, Oregon }\end{array}$ & No differences in turnover rates \\
\hline \multicolumn{3}{|l|}{ Job satisfaction } \\
\hline Decker et al. 2009, The Gerontologist & $\begin{array}{l}\text { 2,146 U.S. CNAs, working } \\
>30 \text { hours a week }\end{array}$ & $\begin{array}{l}\text { FPs: lower intrinsic job satisfaction, } \\
\text { but not lower overall satisfaction }\end{array}$ \\
\hline Choi et al., 2011, The Gerontologist ${ }^{c}$ & $\begin{array}{l}863 \text { RNs in } 282 \text { nursing facilities, } \\
\text { New Jersey }\end{array}$ & FPs: lower RN job satisfaction \\
\hline \multicolumn{3}{|l|}{ Job benefits } \\
\hline $\begin{array}{l}\text { Haley-Lock \& Kruzich, 2008, Nonprofit } \\
\text { and Voluntary Sector Quarterly }\end{array}$ & 54 Wisconsin facilities & $\begin{array}{l}\text { FPs: negatively related to CNA } \\
\text { job benefits }\end{array}$ \\
\hline $\begin{array}{l}\text { Kash et al., 2007, Health Care } \\
\text { Management Review }\end{array}$ & 1,014 Texas facilities & $\begin{array}{l}\text { FPs: lower expenditure on employee } \\
\text { benefits and staff training }\end{array}$ \\
\hline $\begin{array}{l}\text { nership is a covariate. } F P=f c \\
\text { istant; OSCAR }=\text { Online Surv }\end{array}$ & $\begin{array}{l}\text { RNs have the highest level of training, } \\
\text { not-for-profit; RN = Registered Nurse; } \\
\text { n, and Reporting. }\end{array}$ & $\begin{array}{l}\text { lowest. Superscript }{ }^{c} \text { refers to a study in } \\
\text { ensed Vocational Nurse; CNA = Certified }\end{array}$ \\
\hline
\end{tabular}


Staffing. Eleven studies identified staffing level differences between FP and NFP nursing homes and in general found that FP nursing homes have lower staffing levels for direct care professionals. Although five studies found lower staffing levels across all occupational categories (Registered Nurses, Licensed Vocational Nurses, and Certified Nurse Assistants), two other studies only show significant differences one or several occupational categories, but not all (see Table 3). One study failed to find differences in staffing levels between FP and NFP nursing homes (Rantz et al., 2004); another study reports no difference in the staffing of Nurse Practitioners or Physician Assistants (Intrator et al., 2005). None found more favorable staffing levels in FP homes. The results do not show different patterns between studies treating ownership as a central independent variable and those in which ownership was a covariate.

An interesting, high-quality study in this area is by Grabowski and Stevenson (2008), who studied ownership conversions and concluded that staffing levels decrease after a switch from NFP to FP ownership, even after controlling for chain affiliation, case mix, and local economic conditions.

Turnover. A second common variable related to employee well-being is the difference in turnover rates between FP and NFP nursing homes. Although one study found no difference in turnover rates (Castle, Engberg, Anderson, \& Men, 2007), three other studies did find significantly higher turnover rates for all occupational categories in FP nursing homes than in NFP homes (see Table 3). A study, ranked as high quality, by Castle and Engberg (2006) controlled for chain membership and local economic conditions and found higher turnover rates for all occupational categories in FP nursing homes. The study by Kash, Castle, Naufal, and Hawes (2006) similarly controlled for competition, chain membership, and case mix and came to similar conclusions. Castle (2005) also reports higher turnover rates in FP nursing homes. The study that did not find any differences treated ownership as a covariate. We therefore conclude that, overall, the studies provide strong evidence for turnover rates being generally higher in FP nursing homes.

Job satisfaction. The two studies that considered job satisfaction found lower satisfaction scores in FP nursing homes than in NFP nursing homes (see Table 3). However, specific conditions apply to this statement. Although Decker, Harris-Kojetin, and Bercovitz (2009) did find lower intrinsic job satisfaction (which is about responsibility, self-direction, skill development, and observed accomplishments associated with doing the work) in FP homes, the overall job satisfaction was not significantly different between FP and NFP nursing homes. Moreover, the study did not control for relevant variables such as case mix. The other study, by Choi, Flynn, and Aiken (2011), treated ownership as a covariate and found lower Registered Nurse job satisfaction in FP nursing homes.
The evidence thus points toward lower job satisfaction in FP nursing homes, but only under specific conditions, and therefore, we view the evidence as relatively weak.

Job benefits. Two final studies compared job benefits in FP and NFP nursing homes. Both studies controlled for case mix and competition, and Kash et al. (2007) also for chain membership. Both studies report better job benefits in NFP homes (Haley-Lock \& Kruzich, 2008; Kash et al., 2007).

Overall, the studies that have investigated employee wellbeing generally conclude that NFPs have higher staffing levels and lower turnover rates and offer greater job satisfaction and better job benefits.

\section{Profit Status and Client Well-being}

Most of the studies in our review (31 of 50; 62\%) deal with variables that relate to client well-being (see Table 4). In 18 of these studies, ownership is treated as a covariate. Studies on client well-being address two aspects: direct measures of care quality outcomes (such as pressure ulcer incidence and violations of regulations) and indirect measures such as the number of hospitalizations (transfers of nursing home residents to a hospital) and the lawsuit and complaint rates.

The largest group of these studies focuses on direct care quality outcomes (20 studies), and in 12 of these studies, ownership is treated as a covariate. The other studies focus on the number of hospitalizations (10 studies; 6 of them treating ownership as a covariate) and on lawsuit/complaint rates (2 studies in which ownership is a central independent variable).

Care quality. Nine of the 20 studies on direct quality outcomes found no differences between FP and NFP nursing homes. Eight studies identify higher-quality outcomes in NFP nursing homes, whereas three studies report diverse outcomes for different quality indicators, variably favoring FPs and NFPs or finding no differences (see Table 3). None of the studies found FP homes consistently outperforming NFP ones. Most of the studies that treated ownership as a central independent variable included several control variables such as chain affiliation, resident case mix, and competition. Two of the studies that failed to find any differences between FP and NFP nursing homes did not include any control variables (Bardenheier et al., 2005; Zinn et al., 2005).

We have only included medium- and high-quality studies in our review, and here two of the three high-quality studies found worse-quality outcomes in FPs (Amirkhanyan et al., 2008; Konetzka, Yi, et al., 2004). Stevenson and Grabowski (2008), in the other high-quality study, consider ownership conversions. Their study is unique in that it is the only one in our review where the independent ownership variable changed over time. It nuances the negative results seen in other studies in that they show that a change from NFP to FP ownership is not accompanied by a change in care quality. 


\section{Table 4}

\section{Details of studies that assessed client well-being}

\section{Care quality}

Amirkhanyan et al., 2008, Journal of Policy Analysis and Management

Bardenheier et al., 2005, Journal of the American Geriatrics Society

Chesteen, Helgheim, Randall, \&

Wardell, 2005, Journal of

Operations Management

Grabowski \& Stevenson, 2008, Health Services Research

Grabowski et al., 2013, Journal of Health Economics

Lau, Kasper, Potter, \& Lyles, 2004, Health Services Research

Williams, Zimmerman, Sloane, \& Reed, 2005, The Gerontologist

Zinn et al., 2005, The Gerontologist

Akinci \& Krolikowski, 2005, Applied Nursing Research ${ }^{\mathrm{C}}$

Barry, Brannon, \& Mor, 2005, The Gerontologist ${ }^{\mathrm{c}}$

Baumgarten et al., 2004, Journal of the American Geriatrics Society ${ }^{f}$

Castle \& Engberg, 2005, Medical Care ${ }^{c}$

Decker, 2008, Health Economics, Policy, and Law ${ }^{\mathrm{C}}$

Grabowski, 2004, Medical Care ${ }^{c}$

Grabowski \& Angelelli, 2004, Health Services Research ${ }^{c}$

Grabowski et al., 2004, Health Affairs ${ }^{c}$

Kamimura et al., 2007, Health Care Management Review ${ }^{c}$
14,423 U.S. facilities

1,409-1,488 U.S. facilities;

7,374-7,399 residents

(1995/1997/1999)

42 Utah facilities; 890 CNAs

383,937 U.S. facility-quarter records; 194,556 surveys

874,143 U.S. residents

3,372 U.S. nursing home residents

331 Philadelphia residents, 10 nursing homes

16,559 U.S. facilities

90 Pennsylvanian facilities

156 facilities in Maine, Mississippi, New York, Ohio; 156 directors of nursing, 430 day-shift charge nurses

59 Maryland facilities; 1,938 residents

354 U.S. facilities in four states

10,606 U.S. facilities; 21,212 observations

2,690 U.S. nursing home admissions

13,736 U.S. facilities

13,169 to 13,859 U.S. facilities per quality indicator

117 Michigan facilities; 86 North Carolina facilities
FPs: lower quality (violation of regulations)

No significant difference in pneumococcus vaccinations

No differences on outcome quality

Care quality generally does not change following NFP to FP and FP to NFP conversions

FPs: poorer postacute care quality

No difference between FPs and NFPs in potentially inappropriate medication prescriptions

FPs: supervisors more often report resident pain; residents less likely to undergo professional pain assessment and to receive pain medication

FPs (long stay): score worse on pressure sores, restraint use, and the prevalence of infection but better on "loss of ability in daily tasks." No difference for pain. FPs (short stay): score better for delirium and pain; lower percentage "walk as well or better."

FPs: lower quality (violation of regulations)

No significant quality difference for pressure ulcer incidence and resident social engagement

FPs: lower quality (higher incidence of pressure ulcers)

FPs: greater use of physical restraints, no significant differences for catheter use, contractures, pressure ulcers, psychoactive drug use, and deficiencies

FPs: higher restraint use, but not after controlling for the percentage of Medicaid residents, Medicaid payments, occupancy

No difference in number of deficiencies

FPs: higher prevalence of pressure ulcers

FPs: more incidences of pressure ulcers and physical restraints; NFPs: more daily pain

No quality differences (deficiencies, pressure ulcers) between FP and NFP chains

(continues) 


\begin{tabular}{|c|c|c|}
\hline \multicolumn{3}{|c|}{ Table 4} \\
\hline \multicolumn{3}{|c|}{ Details of studies that assessed client well-being, Continued } \\
\hline Reference & Sample & Relevant findings: FP vs. NFP nursing homes \\
\hline $\begin{array}{l}\text { Konetzka, Yi, et al., 2004, } \\
\text { Health Services Research }\end{array}$ & $\begin{array}{l}\text { 18,134 U.S. facilities; } \\
\text { 60,283 surveys }\end{array}$ & FPs: more deficiencies \\
\hline $\begin{array}{l}\text { Konetzka et al., 2006, } \\
\text { Medical Care c }\end{array}$ & $\begin{array}{l}1.704 \text { U.S. facilities, } \\
395,264 \text { residents }\end{array}$ & $\begin{array}{l}\text { No differences on the incidence of urinary } \\
\text { tract infections and pressure sores }\end{array}$ \\
\hline $\begin{array}{l}\text { Zhang \& Grabowski, 2004, } \\
\text { The Gerontologist }\end{array}$ & $\begin{array}{l}5,092 \text { U.S. facilities } \\
\text { in } 22 \text { states }\end{array}$ & $\begin{array}{l}\text { FPs: higher incidence of pressure ulcers, } \\
\text { more catheters used }\end{array}$ \\
\hline \multicolumn{3}{|l|}{ Hospitalizations } \\
\hline $\begin{array}{l}\text { Gozalo \& Miller, 2007, } \\
\text { Health Services Research }\end{array}$ & $\begin{array}{l}183,742 \text { nursing home/hospice } \\
\text { residents in Kansas, } \\
\text { Maine, New York, Ohio, } \\
\text { South Dakota }\end{array}$ & FPs: greater likelihood of hospitalization $(p<.001)$ \\
\hline $\begin{array}{l}\text { Grabowski et al., } 2013 \text {, } \\
\text { Journal of Health Economics }\end{array}$ & $\begin{array}{l}874,143 \text { U.S. nursing } \\
\text { home residents }\end{array}$ & $\begin{array}{l}\text { FPs: poorer postacute care: rehospitalization } \\
\text { after discharge (within } 30 \text { days) more likely }\end{array}$ \\
\hline $\begin{array}{l}\text { Hirth et al., 2014, International } \\
\text { Journal of Health Care } \\
\text { Finance Economics }\end{array}$ & $\begin{array}{l}278,848 \text { U.S. nursing } \\
\text { home residents }\end{array}$ & $\begin{array}{l}\text { FPs: higher hospitalization rates that cannot } \\
\text { be explained by resident differences }\end{array}$ \\
\hline $\begin{array}{l}\text { Konetzka, Spector, et al., 2004, } \\
\text { Medical Care }\end{array}$ & $\begin{array}{l}766 \text { U.S. nursing home } \\
\text { residents suspected of } \\
\text { having pneumonia infections }\end{array}$ & $\begin{array}{l}\text { FPs: higher hospitalization rate for } \\
\text { residents with suspected pneumonia }\end{array}$ \\
\hline $\begin{array}{l}\text { Boockvar et al., 2005, Journal of } \\
\text { the American Geriatrics Society }\end{array}$ & $\begin{array}{l}59 \text { Maryland facilities; 2,285 } \\
\text { residents, follow-up for } \\
\text { 2,153 residents }\end{array}$ & $\begin{array}{l}\text { FPs: increased hospital triage (residents } \\
\text { transferred to hospital within } 3 \text { days of } \\
\text { infection onset, worse resident results) }\end{array}$ \\
\hline Decker, 2006, Medical Care ${ }^{c}$ & 6,386 discharges in U.S. facilities & FPs: hospitalizations more likely \\
\hline Dobalian, 2004, The Gerontologist ${ }^{c}$ & $\begin{array}{l}16,760 \text { U.S. facilities; } 1,560,003 \\
1,536,525 \text { residents }\end{array}$ & FPs: hospitalizations more likely \\
\hline $\begin{array}{l}\text { Intrator, Zinn, \& Mor, 2004, } \\
\text { Journal of the American } \\
\text { Geriatrics Society }\end{array}$ & $\begin{array}{l}54,631 \text { residents; } 663 \text { facilities } \\
\text { in Maine, Kansas, NY, and } \\
\text { South Dakota }\end{array}$ & FPs: hospitalizations more likely \\
\hline $\begin{array}{l}\text { Intrator \& Mor, 2004, Journal of } \\
\text { the American Geriatrics Society }\end{array}$ & $\begin{array}{l}253 \text { nursing homes in } 10 \text { U.S. } \\
\text { states; } 2,080 \text { residents }\end{array}$ & $\begin{array}{l}\text { FPs: higher rate of hospitalization and a } \\
\text { higher rate of death (without hospitalization) } \\
\text { - but not statistically significant }\end{array}$ \\
\hline $\begin{array}{l}\text { Intrator et al., 2007, } \\
\text { Health Services Research c }\end{array}$ & $\begin{array}{l}\text { 570,614 residents; } \\
\text { 8,997 U.S. facilities }\end{array}$ & FPs: higher rate of hospitalizations \\
\hline \multicolumn{3}{|l|}{ Lawsuits/complaints } \\
\hline $\begin{array}{l}\text { Johnson et al., 2004, The } \\
\text { Gerontologist }\end{array}$ & 478 Florida facilities & $\begin{array}{l}\text { FPs: more lawsuits (but very weak } \\
\text { association with ownership type) }\end{array}$ \\
\hline Stevenson, 2005, Medical Care & 539 Massachusetts facilities & FPs: higher rates of complaints \\
\hline
\end{tabular}

Note. Superscript ${ }^{c}$ refers to a study in which ownership is a covariate. FP $=$ for-profit; NFP = not-for-profit.

Overall, most studies report no difference between the care quality provided in FP and NFP nursing homes. Although several studies do suggest better care in NFP homes, none of the studies found that FP nursing homes consistently outperform NFP ones on this variable.

Hospitalizations. When it comes to the number of hospitalizations, the evidence is clear-cut: FP nursing homes show higher hospitalization rates than their NFP counterparts (see Table 4). The high-quality study by Hirth, Grabowski, Feng, Rahman, and Mor (2014) suggests that the higher hospitalization rates in FP nursing homes are due to a greater willingness or ability of NFP nursing homes to manage cases in-house. Their study also shows that differences cannot be explained by resident characteristics. Konetzka, Spector, et al. (2004) in another high-quality study, after controlling for chain affiliation, resident payer sources, and resident characteristics, find evidence for higher hospitalization rates for residents with suspected pneumonia in FPs. We therefore conclude that the evidence showing higher hospitalization rates in FP nursing homes is convincing.

Lawsuit/complaint rates. The two studies that emerged from our search that addressed lawsuits and complaints both show a higher rate of lawsuits and complaints in 
FP nursing homes after controlling for facility size (see Table 4). Johnson, Dobalian, Burkhard, Hedgecock, and Harman (2004, p. 344) found that litigation activity was $19 \%$ higher in FP homes than in NFP ones. Stevenson (2005) found that FP nursing homes have higher complaint rates.

Overall, none of the studies reviewed found that FP nursing homes consistently outperform NFP ones in terms of direct care quality indicators, whereas several studies found that NFP nursing homes scored more highly on a range of quality indicators. Furthermore, FP nursing homes show higher hospitalization rates and are subject to more lawsuits and complaints.

\section{$\overline{\text { Profit }}$ Status and Multidimensional Performance}

In the available evidence, FP nursing homes demonstrate better financial performance than their NFP counterparts, with higher profit margins and greater efficiency. However, these positive findings with regard to financial performance do not go hand in hand with positive findings for employee well-being and client well-being. FP nursing homes tend to have lower staffing levels, higher turnover rates, lower job satisfaction, and less job benefits than NFP nursing homes. Likewise, with regard to client well-being, FP homes are more likely to score worse on care quality outcomes, have higher hospitalization rates of their residents, and are more often the target of complaints or lawsuits. Most of these results are robust, controlling for relevant variables such as market features, resident characteristics, and sometimes also chain affiliation. Although Hirth (1999) warned of a potential bias in the ownership-quality literature because competition was not taken into account, more recent research does often control for competition (e.g., Amirkhanyan et al., 2008; Grabowski et al., 2013; Grabowski \& Stevenson, 2008; Kash et al., 2007).

Here, we employ a multistakeholder perspective in which we combine the results from all 50 studies.

First, based on the results, it seems that policies and procedures that improve profit margins and efficiency require strict control over personnel costs and resident costs. The suggestion that deteriorating client well-being can be partly blamed on the FP motive is certainly not undermined by our review of the last 10 years of literature. If anything, the "conflicting outcomes perspective" is supported with regard to "financial performance" versus "employee wellbeing" and "client well-being": Although a nursing home's FP status can be associated with positive financial performance, it can at the same time be related to predominantly worse outcomes in terms of employee and client well-being. Only one of the studies included in our review combines financial performance and employee well-being, and this found that higher profit margins in FP nursing homes are matched by lower expenditure on employee benefits and staff training (Kash et al., 2007). This leads to the first proposition drawn from our systematic review:

\section{Proposition 1: The "conflicting outcomes" perspective applies to FP nursing homes in that better financial performance is associated with worse employee and client well-being.}

Second, it seems that poor results for employee wellbeing appear to go together with negative outcomes for client well-being in FP nursing homes. The three studies that combined staffing and direct care quality measures (Akinci \& Krolikowski, 2005; Decker, 2008; Konetzka, Yi, et al., 2004) all showed this pattern. Grabowski and Stevenson (2008) presented a more nuanced picture in that the decreasing staffing levels in nursing homes converting from NFP to FP did not lead to changes in the direct care quality indicators. As such, the "mutual gains perspective" seems applicable to employee well-being and client well-being, leading to our second proposition:

Proposition 2: The "mutual gains" perspective applies to FP nursing homes insofar as better employee wellbeing is associated with better client well-being.

Figure 3 provides a summary of the findings and the propositions.

\section{Conclusions and Implications}

\section{Conclusions}

The implications of FP ownership of nursing homes have been a controversial subject for decades. Concerns are expressed that the focus on profits comes at the expense of care quality for the frail and elderly people that reside in nursing homes. An extensive body of research exists on the differences between FP and NFP nursing homes. To date, individual articles and reviews have largely focused on client well-being or employee well-being or financial performance, whereas the discussions on the significance of profit status in nursing homes are often about the interaction between these outcomes. The reviews by Comondore et al. (2009) and Hillmer et al. (2005) both show a lower quality of care in FP nursing homes compared with NFP ones. Our systematic review of the literature on FP nursing home ownership and its effects over the last 10 years shows that these earlier outcomes are largely supported by more recent research, although we also report articles that fail to find care quality differences between FP and NFP nursing homes. Going beyond recent reviews of the effects of nursing home profit status, we apply a multistakeholder perspective that results in a multidimensional performance 
Figure 3

Summary of the findings and the propositions

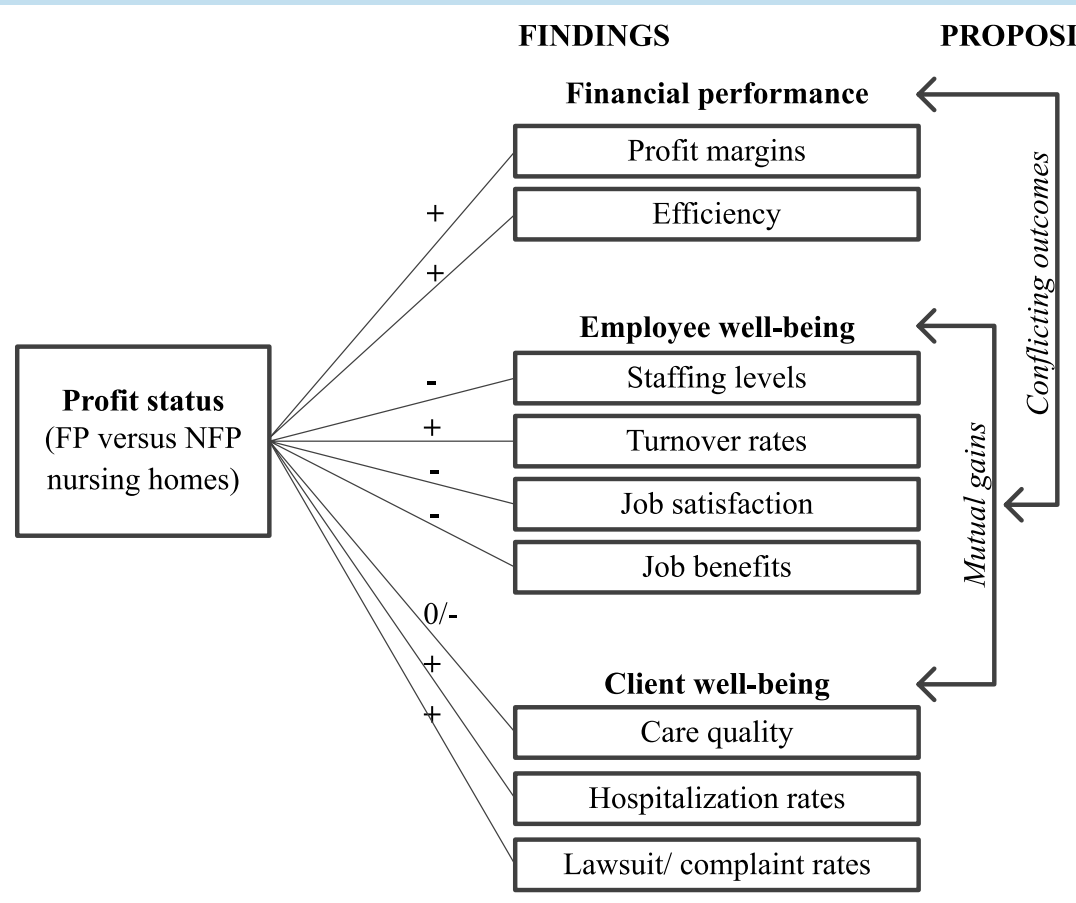

The figure shows the differences between for-profit (FP) and not-for-profit (NFP) nursing homes. A "+" means that FP nursing homes generally score higher on this variable than NFP nursing homes, a "-" means that FP nursing homes generally score lower than NFP nursing homes. A " 0 " means that there is no difference between FP and NFP nursing homes.

construct that incorporates financial performance, employee well-being, and client well-being. FP nursing homes, when compared to their NFP counterparts, show better financial performance but tend to score worse on most employee well-being and client well-being variables. These outcomes are robust, and we did not find differences between studies in which ownership is the central independent variable and those in which ownership is a covariate (which can be interpreted as an indicator of the absence of publication bias). Furthermore, the high-quality studies at the center of our review include relevant control variables such as case mix, chain affiliation, and per capita income.

\section{Implications for Research}

This review has several limitations, which we now consider, and these often suggest opportunities for future research. First, we adopted the operationalizations and measurements of the dependent variables directly from the individual papers reviewed. As such, there is some variation in the way the individual measures of the dependent variables, such as care quality or profit margins, are defined.
Second, we found only very limited research into several of the variables addressed, and this calls for further research. For example, not many studies address financial performance or several of the employee level variables such as employee satisfaction. Most of the research to date has focused on client well-being variables and especially on care quality. Furthermore, the focus in care quality measurements is on clinical measures, such as pressure ulcer prevalence. Given that people often spend the last years of their lives in nursing homes, we would suggest adding broader quality of life indicators such as social engagement, client satisfaction, and family caregiver satisfaction (e.g., Gawande, 2014; Li et al., 2013).

Third, the results of this review suggest that the consequences of the profit status of a nursing home can in different aspects be interpreted as conforming to the conflicting outcomes perspective as well as to the mutual gains perspective. Our conclusions are largely based on separate studies that cover varying samples while focusing on a single stakeholder. We would encourage future research to combine variables that are relevant for multiple stakeholders in a single study and investigate whether our propositions 
can be supported. We also suggest that it would be particularly valuable to study ownership conversions (from NFP to FP) to see if any changes occur in financial performance, employee well-being, and client well-being after conversion (e.g., Grabowski \& Stevenson, 2008).

Fourth, the distinction we made between FP and NFP might be too coarse (Meagher \& Cortis, 2009, p. 35). The debate on nursing home ownership is entering a new phase in which attention is shifting from the FP and NFP divide to the complicated ownership structures seen within the FP sector (Stevenson, Bramson, \& Grabowski, 2013), including the role of private equity owners (e.g., Harrington, Olney, Carrillo, \& Kang, 2012; Pradhan, Weech-Maldonado, Harman, Laberge, \& Hyer, 2013; Stevenson \& Grabowski, 2008). The early empirical studies on this topic, for example, show that private equity-owned nursing homes have higher operating and total margins than other FP nursing homes. The differences within FP nursing home ownership therefore seem worthy of a study in their own right. At the same time, researchers need to be more precise with regard to NFP nursing homes. Twenty-nine of the 50 studies included in our review treated profit status as a dummy (yes/no) variable, often without making clear if the NFP category includes only private NFP nursing homes, or also public nursing homes. Because public homes often work for particular populations or serve as safety net providers (e.g., Grabowski et al., 2013), it would help clarify outcomes if results were specifically tied to NFP or to public providers. The indistinct dividing line between private NFP and public homes is a weakness of existing research that placed limitations on our review.

Fifth, we used broad search terms in finding articles relevant for this review. The broad scope of the search terms enabled us to identify a wide range of potentially relevant articles. At the same time, more specific search terms (such as "family caregiver satisfaction") might have revealed other publications that were not included in this review.

Finally, the review focuses on studies based in the United States, where the majority of nursing homes are "for-profits." The relatively few NFP nursing homes in the United States "tend to focus on the clinically more severe and financially more lucrative end of the payer spectrum," whereas FP facilities "usually have a less lucrative payer mix" (Konetzka, 2009, p. 339). As we noted in our introduction, other Western countries are increasingly seeing it as desirable to extend the availability of FP nursing homes. In contrast to the United States, NFP nursing homes in these countries may emphasize a community-oriented mission, including care for the less profitable patients. Furthermore, in the United States, NFP nursing homes are granted some specific advantages including income and property tax exemptions and access to tax-deductible donations and bonds (Hirth et al., 2014). Translating the finding from our review to other territories therefore needs caution. Some studies in Canada and Finland have indicated that outcomes are in- deed similar in terms of employee well-being (e.g., Heponiemi, Elovainio, Kouvonen, Kuusio, et al., 2011; Heponiemi, Elovainio, Kouvonen, Noro, et al., 2011; McGregor et al., 2005) and client well-being variables (e.g., McGregor et al., 2006, 2011). However, further research is needed in other countries to determine whether outcomes are similar in different institutional contexts.

\section{Implications for Practice}

For policy makers considering the expansion of the FP nursing home industry, our findings suggest the need to adopt a broad perspective, simultaneously weighing up the potential benefits and drawbacks for the organization as a whole, for its employees, and for its clients. Careful consideration is needed in balancing the results on the different dimensions for multiple stakeholders. This is true in any situation, and one needs to be cautious in applying findings in one country (e.g., the United States) to elsewhere. As mentioned earlier, the outcomes of this review might reflect an underlying distinction in the U.S. nursing home industry with its two-tier system. In this system, the superior care quality offered in NFP nursing homes is related to their inclination to shun Medicaid patients because these provide less money for health services. FP nursing homes are more willing to accept Medicaid recipients but may well offer a reduced care quality. This leads to a situation "in which elitist NFP providers serve healthier, more educated, and affluent consumers and FP homes provide substandard quality to everyone else" (Amirkhanyan, 2008, p. 676; Mor, Zinn, Angelelli, Teno, \& Miller, 2004). Given these concerns, it is important to remember that all the high-quality studies in our review controlled for market variables that might distort the relationship between ownership type and the dependent variables. Here, the high-quality studies controlled for poverty rates, per capita income, or for the percentage of Medicaid recipients in the area where a nursing home was located (see Appendix A, Supplemental Digital Content 1, http://links.lww.com/HCMR/A17). Moreover, the first set of studies in other Western countries point in the same direction as U.S. studies in terms of employee wellbeing and client well-being. The evidence thus emphasizes the continuing importance of nursing home ownership in policy decisions on the structuring of a sustainable nursing home industry.

\section{Acknowledgments}

The authors thank Rachel B. Edwards, David Grabowski, Ann Gruber-Baldini, Bita Kash, Tamara Konetzka, and David Stevenson for reviewing a list of potential articles and for providing helpful suggestions on further articles. 


\section{References}

* Study included in systematic review.

Aiken, L. H., Clarke, S. P., Sloane, D. M., Sochalski, J., \& Silber, J. H. (2002). Hospital nurse staffing and patient mortality, nurse burnout, and job dissatisfaction. JAMA, 288(16), 1987-1993.

* Akinci, F., \& Krolikowski, D. (2005). Nurse staffing levels and quality of care in Northeastern Pennsylvania nursing homes. Applied Nursing Research, 18(3), 130-137.

Amirkhanyan, A. (2008). Privatizing public nursing homes: Examining the effects on quality and access. Public Administration Review, 68(4), 665-680.

* Amirkhanyan, A. A., Kim, H. J., \& Lambright, K. T. (2008). Does the public sector outperform the nonprofit and for-profit sectors? Evidence from a national panel study on nursing home quality and access. Journal of Policy Analysis and Management, 27(2), 326-353.

* Bardenheier, B., Shefer, A., Tiggle, R., Marsteller, J., \& Remsburg, R. E. (2005). Nursing home resident and facility characteristics associated with pneumococcal vaccination: $\mathrm{Na}$ tional nursing home survey, 1995-1999. Journal of the American Geriatrics Society, 53(9), 1543-1551.

* Barry, T., Brannon, D., \& Mor, V. (2005). Nurse aide empowerment strategies and staff stability: Effects on nursing home resident outcomes. The Gerontologist, 45(3), 309-317.

Batt, R., \& Colvin, A. J. (2011). An employment systems approach to turnover: Human resources practices, quits, dismissals, and performance. Academy of Management Journal, 54(4), 695-717.

* Baumgarten, M., Margolis, D., Van Doorn, C., Gruber-Baldini, A. L., Hebel, J. R., Zimmerman, S., \& Magaziner, J. (2004). Black/ White differences in pressure ulcer incidence in nursing home residents. Journal of the American Geriatrics Society, 52(8), 1293-1298.

Beer, M., Spector, B., Lawrence, P., Mills, D. Q., \& Walton, R. (1984). Human resource management: A general manager's perspective. New York, NY: Free Press.

Ben-Ner, A., \& Ren, T. (2008). Does organization ownership matter? Structure and performance in for-profit, nonprofit, and local government nursing homes. Paper presented at the Industry Studies Annual Conference, Boston (USA), May 1-2, 2008.

* Boockvar, K. S., Gruber-Baldini, A. L., Burton, L., Zimmerman, S., May, C., \& Magaziner, J. (2005). Outcomes of infection in nursing home residents with and without early hospital transfer. Journal of the American Geriatrics Society, 53(4), 590-596.

Bronkhorst, B., Tummers, L. G., Steijn, B., \& Vijverberg, D. (2014). Organizational climate and employee mental health outcomes: A systematic review of studies in health care organizations. Health Care Management Review, 40(3), 254-271.

* Castle, N. G. (2005). Turnover begets turnover. The Gerontologist, 45(2), 186-195.

* Castle, N. G., \& Engberg, J. (2005). Staff turnover and quality of care in nursing homes. Medical Care, 43(6), 616-626.

* Castle, N. G., \& Engberg, J. (2006). Organizational characteristics associated with staff turnover in nursing homes. The Gerontologist, 46(1), 62-73.

* Castle, N. G., Engberg, J., Anderson, R., \& Men, A. (2007). Job satisfaction of nurse aides in nursing homes: Intent to leave and turnover. The Gerontologist, 47(2), 193-204.

Centers for Medicare and Medicaid Services. (2013). Nursing home data compendium 2013. Washington, DC : U.S. Department of Health and Human Services.

* Chesteen, S., Helgheim, B., Randall, T., \& Wardell, D. (2005). Comparing quality of care in non-profit and for-profit nursing homes: A process perspective. Journal of Operations Management, 23(2), 229-242.

* Choi, J., Flynn, L., \& Aiken, L. H. (2011). Nursing practice environment and registered nurses' job satisfaction in nursing homes. The Gerontologist, gnr101.

Comondore, V. R., Devereaux, P. J., Zhou, Q., Stone, S. B., Busse, J. W., Ravindran, N. C., ... Guyatt, G. H. (2009). Quality of care in for-profit and not-for-profit nursing homes: Systematic review and meta-analysis. BMJ, 339, b2732.

Cummings, G. C., MacGregor, T., Davey, M., Lee, H., Wong, C. A., Lo, E., ... Stafford, E. (2010). Leadership styles and outcome patterns for the nursing workforce and work environment: A systematic review. International Journal of Nursing Studies, 47, 363-385.

* Davis, J. A., Marino, L. D., Aaron, J. R., \& Tolbert, C. L. (2009). An examination of entrepreneurial orientation, environmental scanning, and market strategies of nonprofit and for-profit nursing home administrators. In Nonprofit and Voluntary Sector Quarterly.

* Decker, F. H. (2006). Nursing staff and the outcomes of nursing home stays. Medical Care, 44(9), 812-821.

* Decker, F. H. (2008). Nursing home performance in resident care in the United States: Is it only a matter of for-profit versus not-for-profit? Health Economics, Policy, and Law, 3(Pt. 2), 115-140.

* Decker, F. H., Harris-Kojetin, L. D., \& Bercovitz, A. (2009). Intrinsic job satisfaction, overall satisfaction, and intention to leave the job among nursing assistants in nursing homes. The Gerontologist, 49(5), 596-610.

* Dobalian, A. (2004). Nursing facility compliance with do-nothospitalize orders. The Gerontologist, 44(2), 159-165.

Dyson, R. (2014, April 11). Care homes: How much profit should they make? The Telegraph. Retrieved from http://www. telegraph.co.uk/finance/personalfinance/10761167/Carehomes-how-much-profit-should-they-make.html

European Commission. (2012). The 2012 ageing report, economic and budgetary projections for the 27 EU member states (20102060). European Economy. Economical and Financial Affairs. Brussels, Belgium: Author.

Falck, O., \& Heblich, S. (2007). Corporate social responsibility: Doing well by doing good. Business Horizons, 50(3), 247-254.

* Feng, Z., Grabowski, D. C., Intrator, O., Zinn, J., \& Mor, V. (2008). Medicaid payment rates, case-mix reimbursement, and nursing home staffing-1996-2004. Medical Care, 46(1), 33-40.

Forder, J., \& Allan, S. (2011). Competition in the care homes market. London/Kent: OHE Commission on Competition, National Health Service.

Freeman, R. E., Harrison, J. S., Wicks, A. C., Parmar, B. L., \& De Colle, S. (2010). Stakeholder theory: The state of the art. Cambridge, UK: Cambridge University Press.

Gawande, A. (2014). Being mortal. New York, NY: Metropolitan Books. * Givens, J. L., Mitchell, S. L., Kuo, S., Gozalo, P., Mor, V., \& Teno, J. (2013). Skilled nursing facility admissions of nursing home residents with advanced dementia. Journal of the American Geriatrics Society, 61(10), 1645-1650.

Givens, J. L., Selby, K., Goldfeld, K. S., \& Mitchell, S. L. (2012). 
Hospital transfers of nursing home residents with advanced dementia. Journal of the American Geriatrics Society, 60(5), 905-909.

* Gozalo, P. L., \& Miller, S. C. (2007). Hospice enrollment and evaluation of its causal effect on hospitalization of dying nursing home patients. Health Services Research, 42(2), 587-610.

* Grabowski, D. C. (2004). The admission of blacks to highdeficiency nursing homes. Medical Care, 42(5), 456-464.

* Grabowski, D. C., \& Angelelli, J. J. (2004). The relationship of Medicaid payment rates, bed constraint policies, and riskadjusted pressure ulcers. Health Services Research, 39(4 Pt. 1), 793-812.

* Grabowski, D. C., Angelelli, J. J., \& Mor, V. (2004). Medicaid payment and risk-adjusted nursing home quality measures. Health Affairs, 23(5), 243-252.

* Grabowski, D. C., Feng, Z., Hirth, R., Rahman, M., \& Mor, V. (2013). Effect of nursing home ownership on the quality of post-acute care: An instrumental variables approach. Journal of Health Economics, 32(1), 12-21.

* Grabowski, D. C., \& Stevenson, D. G. (2008). Ownership conversions and nursing home performance. Health Services Research, 43(4), 1184-1203.

* Haley-Lock, A., \& Kruzich, J. (2008). Serving workers in the human services: The roles of organizational ownership, chain affiliation, and professional leadership in frontline job benefits. Nonprofit and Voluntary Sector Quarterly, 37(3), 443-467.

Harrington, C., Olney, B., Carrillo, H., \& Kang, T. (2012). Nurse staffing and deficiencies in the largest for-profit nursing home chains and chains owned by private equity companies. Health Services Research, 47(1), 106-128.

Harrington, C., Zimmerman, D., Karon, S. L., Robinson, J., \& Beutel, P. (2000). Nursing home staffing and its relationship to deficiencies. The Journals of Gerontology. Series B, Psychological Sciences and Social Sciences, 55, S278-S287.

Harter, J. K., Schmidt, F. L., \& Hayes, T. L. (2002). Business-unitlevel relationship between employee satisfaction, employee engagement, and business outcomes: A meta-analysis. Journal of Applied Psychology, 87(2), 268.

Heponiemi, T., Elovainio, M., Kouvonen, A., Kuusio, H., Noro, A., Finne-Soveri, H., \& Sinervo, T. (2011). The effects of ownership, staffing level and organisational justice on nurse commitment, involvement, and satisfaction: A questionnaire study. International Journal of Nursing Studies, 48(12), 1551-1561.

Heponiemi, T., Elovainio, M., Kouvonen, A., Noro, A., Finne Soveri, H., \& Sinervo, T. (2011). Ownership type and team climate in elderly care facilities: The moderating effect of stress factors. Journal of Advanced Nursing, 68(3), 647-657.

Hillmer, M. P., Wodchis, W. P., Gill, S. S., Anderson, G. M., \& Rochon, P. A. (2005). Nursing home profit status and quality of care: Is there any evidence of an association? Medical Care Research and Review, 62(2), 139-166.

Hirth, R. A. (1999). Consumer information and competition between nonprofit and for-profit nursing homes. Journal of Health Economics, 18(2), 219-240.

* Hirth, R. A., Grabowski, D. C., Feng, Z., Rahman, M., \& Mor, V. (2014). Effect of nursing home ownership on hospitalization of long-stay residents: An instrumental variables approach. International Journal of Health Care Finance and Economics, 14(1), 1-18.

* Intrator, O., Feng, Z., Mor, V., Gifford, D., Bourbonniere, M., $\&$ Zinn, J. (2005). The employment of nurse practitioners and physician assistants in U.S. nursing homes. The Gerontologist, 45(4), 486-495.

* Intrator, O., Grabowski, D. C., Zinn, J., Schleinitz, M., Feng, Z., Miller, S., \& Mor, V. (2007). Hospitalization of nursing home residents: The effects of states' Medicaid payment and bedhold policies. Health Services Research, 42(4), 1651-1671.

* Intrator, O., \& Mor, V. (2004). Effect of state Medicaid reimbursement rates on hospitalizations from nursing homes. Journal of the American Geriatrics Society, 52(3), 393-398.

* Intrator, O., Zinn, J., \& Mor, V. (2004). Nursing home characteristics and potentially preventable hospitalizations of long-stay residents. Journal of the American Geriatrics Society, 52(10), 1730-1736.

* Johnson, C. E., Dobalian, A., Burkhard, J., Hedgecock, D. K., \& Harman, J. (2004). Factors predicting lawsuits against nursing homes in Florida 1997-2001. The Gerontologist, 44(3), 339-347.

* Kamimura, A., Banaszak-Holl, J., Berta, W., Baum, J. A., Weigelt, C., \& Mitchell, W. (2007). Do corporate chains affect quality of care in nursing homes? The role of corporate standardization. Health Care Management Review, 32(2), 168-178.

* Kash, B. A., Castle, N. G., Naufal, G. S., \& Hawes, C. (2006). Effect of staff turnover on staffing: A closer look at registered nurses, licensed vocational nurses, and certified nursing assistants. The Gerontologist, 46(5), 609-619.

* Kash, B. A., Castle, N. G., \& Phillips, C. D. (2007). Nursing home spending, staffing, and turnover. Health Care Management Review, 32(3), 253-262.

Kirsebom, M., Hedström, M., Wadensten, B., \& Pöder, U. (2014). The frequency of and reasons for acute hospital transfers of older nursing home residents. Archives of Gerontology and Geriatrics, 58(1), 115-120.

Kitchener, M., O’Meara, J., Brody, A., Lee, H. Y., \& Harrington, C. (2008). Shareholder value and the performance of a large nursing home chain. Health Services Research, 43(3), 1062-1084.

Konetzka, R. T. (2009). Do not-for-profit nursing homes provide better quality? BMJ, 339, b2683.

* Konetzka, R. T., Norton, E. C., Sloane, P. D., Kilpatrick, K. E., $\&$ Stearns, S. C. (2006). Medicare prospective payment and quality of care for long-stay nursing facility residents. Medical Care, 44(3), 270-276.

* Konetzka, R. T., Spector, W., \& Shaffer, T. (2004). Effects of nursing home ownership type and resident payer source on hospitalization for suspected pneumonia. Medical Care, 42(10), 1001-1008.

* Konetzka, R. T., Yi, D., Norton, E. C., \& Kilpatrick, K. E. (2004). Effects of Medicare payment changes on nursing home staffing and deficiencies. Health Services Research, 39(3), 463-488.

Lakhani, N., \& Whittell, R. (2012, November 5). Who owns the care homes - and why are they so in debt? The Independent. Retrieved from http://www.independent.co.uk/news/uk/ home-news/who-owns-the-care-homes-and-why-are-they-soin-debt-8281273.html

Laschinger, H. K. S., \& Leiter, M. P. (2006). The impact of nursing work environments on patient safety outcomes: The mediating role of burnout engagement. Journal of Nursing Administration, 36(5), 259-267.

Laszlo, C. (2008). Sustainable value: How the world's leading companies are doing well by doing good. Stanford, CA: Stanford University Press. 
* Lau, D. T., Kasper, J. D., Potter, D. E. B., \& Lyles, A. (2004). Potentially inappropriate medication prescriptions among elderly nursing home residents: Their scope and associated resident and facility characteristics. Health Services Research, 39(5), 1257-1276.

* Lee, R. H., Bott, M. J., Gajewski, B., \& Taunton, R. L. (2009). Modeling efficiency at the process level: An examination of the care planning process in nursing homes. Health Services Research, 44(1), 15-32.

Li, Y., Cai, X., Ye, Z., Glance, L. G., Harrington, C., \& Mukamel, D. B. (2013). Satisfaction with Massachusetts nursing home care was generally high during 2005-09, with some variability across facilities. Health Affairs, 32(8), 1416-1425.

Liberati, A., Altman, D. G., Tetzlaff, J., Mulrow, C., Gøtzsche, P. C., Ioannidis, J. P., ... Moher, D. (2009). The PRISMA statement for reporting systematic reviews and meta-analyses of studies that evaluate health care interventions: Explanation and elaboration. Annals of Internal Medicine, 151(4), W65-W94.

Macky, K., \& Boxall, P. (2007). The relationship between "highperformance work practices" and employee attitudes: An investigation of additive and interaction effects. The International Journal of Human Resource Management, 18(4), 537-567.

McGregor, M. J., Cohen, M., McGrail, K., Broemeling, A. M., Adler, R. N., Schulzer, M., ... Beck, M. (2005). Staffing levels in not-for-profit and for-profit long-term care facilities: Does type of ownership matter? Canadian Medical Association Journal, 172(5), 645-649.

McGregor, M. J., Cohen, M., Stocks-Rankin, C. R., Cox, M. B., Salomons, K., McGrail, K. M., ... Schulzer, M. (2011). Complaints in for-profit, non-profit and public nursing homes in two Canadian provinces. Open Medicine, 5(4), e183-e192.

McGregor, M. J., Tate, R. B., McGrail, K. M., Ronald, L. A., Broemeling, A. M., \& Cohen, M. (2006). Care outcomes in long-term care facilities in British Columbia, Canada: Does ownership matter? Medical Care, 44(10), 929-935.

Meagher, G., \& Cortis, N. (2009). The political economy of for-profit paid care: theory and evidence. In D. King, \& G. Meagher, (Eds.), Paid care in Australia: Politics, profits, practices, (pp. 13-42). Sydney, Australia: Sydney University Press.

Mor, V., Zinn, J., Angelelli, J., Teno, J. M., \& Miller, S. C. (2004). Driven to tiers: Socioeconomic and racial disparities in the quality of nursing home care. Milbank Quarterly, 82(2), 227-256.

* Mueller, C., Arling, G., Kane, R., Bershadsky, J., Holland, D., \& Joy, A. (2006). Nursing home staffing standards: Their relationship to nurse staffing levels. The Gerontologist, 46(1), 74-80.

* Park, J., \& Stearns, S. C. (2009). Effects of state minimum staffing standards on nursing home staffing and quality of care. Health Services Research, 44(1), 56-78.

Pradhan, R., Weech-Maldonado, R., Harman, J. S., Laberge, A., \& Hyer, K. (2013). Private equity ownership and nursing home financial performance. Health Care Management Review, 38(3), 224-233.

Ramsay, H., Scholarios, D., \& Harley, B. (2000). Employees and high-performance work systems: Testing inside the black box. British Journal of Industrial Relations, 38(4), 501-531.

* Rantz, M. J., Hicks, L., Grando, V., Petroski, G. F., Madsen, R. W., Mehr, D. R., ... Maas, M. (2004). Nursing home quality, cost, staffing, and staff mix. The Gerontologist, 44(1), 24-38.
Schnelle, J. F., Simmons, S. F., Harrington, C., Cadogan, M., Garcia, E., \& Bates-Jensen, M. B. (2004). Relationship of nursing home staffing to quality of care. Health Services Research, 39(2), 225-250.

* Seblega, B. K., Zhang, N. J., Unruh, L. Y., Breen, G. M., Paek, S. C., \& Wan, T. T. (2010). Changes in nursing home staffing levels, 1997 to 2007. Medical Care Research and Review, $67(2), 232-246$.

Sengupta, M., Harris-Kojetin, L. D., \& Caffrey, C. (2015). Variation in residential care community resident characteristics, by size of community: United States, 2014 (NCHS Data Brief, No. 223). Retrieved from http://www.cdc.gov/nchs/data/ databriefs/db223.pdf

Sennero, J., \& Pollard, N. (2014, October 6). Swedish government strikes deal with Left to limit welfare profits. Reuters. Retrieved from http://www.reuters.com/article/us-swedenpolitcs-welfare-idUSKCNOHV11V20141006

*Stevenson, D. G. (2005). Nursing home consumer complaints and their potential role in assessing quality of care. Medical Care, 43(2), 102-111.

Stevenson, D. G., Bramson, J. S., \& Grabowski, D. C. (2013). Nursing home ownership trends and their impacts on quality of care: a study using detailed ownership data from Texas. Journal of Aging \& Social Policy, 25(1), 30-47.

Stevenson, D. G., \& Grabowski, D. C. (2008). Private equity investment and nursing home care: Is it a big deal? Health Affairs, 27(5), 1399-1408.

U.S. Department of Health and Human Services, Public Health Service, National Center for Health Statistics. (2013). Longterm care services in the United States: 2013 Overview. Vital E) Health Statistics, Analytical and Epidemiological Studies, 3(37), 1-107.

U.S. Government Accountability Office. (2010). Poorly performing nursing homes. Special focus facilities are often improving, but CMS's program could be strengthened. Washington, DC: Author.

Van De Voorde, K., Paauwe, J., \& Van Veldhoven, M. (2012). Employee well-being and the HRM-organizational performance relationship: A review of quantitative studies. International Journal of Management Reviews, 14(4), 391-407.

Van Veldhoven, M. (2005). Financial performance and the longterm link with HR practices, work climate and job stress. Human Resource Management Journal, 15(4), 30-53.

* Weech-Maldonado, R., Laberge, A., Pradhan, R., Johnson, C. E., \& Hyer, K. (2012). Nursing home financial performance: The role of ownership and chain affiliation. Health Care Management Review, 37(3), 235-245.

* Williams, C. S., Zimmerman, S., Sloane, P. D., \& Reed, P. S. (2005). Characteristics associated with pain in long-term care residents with dementia. The Gerontologist, 45(1), 68-73.

* Zhang, X., \& Grabowski, D. C. (2004). Nursing home staffing and quality under the Nursing Home Reform Act. The Gerontologist, 44(1), 13-23.

* Zhang, N. J., Unruh, L., \& Wan, T. T. (2008). Has the Medicare prospective payment system led to increased nursing home efficiency? Health Services Research, 43(3), 1043-1061.

* Zinn, J., Spector, W., Hsieh, L., \& Mukamel, D. B. (2005). Do trends in the reporting of quality measures on the nursing home compare web site differ by nursing home characteristics? The Gerontologist, 45(6), 720-730. 